Government publications, and that geology, physics, metallurgy and chemistry are well covered; biology is not dealt with, as there is a similar journal in this field. The new journal will serve a very useful pur. pose, since it gives at a glance the titles of papers in a wide field. The format is very convenient.

\section{Fifth Glass Convention}

The fifth Glass Convention will be held at the Norbury House Hotel, Droitwich, on May 18-21 under the presidency of Mr. H. S. Williams-Thomas. This year will be an important one in the history of the British glass industry because in London the Society of Glass Technology has just concluded its twenty-first anniversary celebrations, and in April the Daily Mail Ideal Home Exhibition at Olympia will have glass as its outstanding motive. A subject which is engaging the attention of industrialists at the moment is the trade cycle, on which Mr. Harold Macmillan, M.P., will speak during one of the business sessions. Mr. Ronald Cartland, M.P., will give an address on "Recent Industrial Legislation". The presidential address will be entitled "Craftsmanship in Industry". Prof. W. E. S. Turner will lead the discussion on the presidential address. Of no less interest are the technical sessions arranged by the Society of Glass Technology, the subjects being "Glass Finishing Processes" and "Plastics and their Relation to the Glass Industry".

\section{Announcements}

SIR JOHN SNELI, chairman of the Electricity Commission, has been awarded the Faraday Medal of the Institution of Electrical Engineers. The Medal is awarded once a year either for notable scientific or industrial achievement in electrical engineering or for conspicuous service rendered to the advancement of electrical science, without restriction as regards nationality, country of residence, or membership of the institution. Mr. Frank Gill, past president of the Institution, has been elected an honorary member of the Council of the Institution.

The Messel Medal of the Society of Chemical Industry has been awarded to Prof. L. H. Baekeland, honorary professor of chemical engineering in Columbia University. Prof. L. H. Baekeland is the founder of the plastics industry and his own name is perpetuated in the well-known commodity 'Bakelite'. He was also responsible for the 'Velox' patents used in modern photographic industry. The Messel Medal is awarded every two years for meritorious distinction in science and its application to industry.

Dr. E. W. Russelu has been appointed Goldsmiths' Company's soil physicist at the Rothamsted Experimental Station in succession to Dr. G. W. Scott Blair, who has been appointed head of the Dairy Chemistry Department at the National Institute for Research in Dairying, Shinfield, Reading. Dr. Russell studied soil science at Zurich under Prof. Wiegner and in Russia under Prof. Polynov; for the past few years he has been assistant in the Soil Physics Department, Rothamsted, and has published various papers on soil texture.

AT the annual general meeting of the Royal Meteorological Society on January 19, Dr. B. A. Keen, assistant director, Rothamsted Experimental Station, Harpenden, was elected president in succession to Dr. F. J. W. Whipple. Other officers elected include: Secretaries, H. W. L. Absalom, W. Dunbar, E. L. Hawke; Treasurer, W. M. Witchell ; New Members of Council, C. E. Britton, Dr. R. F. Fox, Major H. C. Gunton, R. S. Read, Gerald Seligman and Dr. R. C. Sutcliffe.

THE following have been elected officers of the Royal Microscopical Society for the present year: President: J. E. Barnard; Hon. Treasurer : C. F. Hill; Hon. Secretaries : Prof. R. T. Hewlett and J. Smiles; New Members of Council: Dr. J. A. Murray, J. H. Pledge, T. E. Wallis and S. R. Wycherley; Hon. Editor: Dr. G. M. Findlay; Hon. Librarian: Dr. C. Tierney; Hon. Curator of Instruments : M. T. Denne; Hon. Curator of Slides : N. Ingram Hendey.

THE forty-first Bedson Lecture will be delivered by Prof. J. Kenner, professor of technological chemistry, University of Manchester, at King's College, New. castle-upon-Tyne, on Friday, February 4. Prof. Kenner will take as his subject "Aliphatic Diazo Compounds".

Prof. Bernard Nocht of Hamburg has been awarded the shield of nobility of the German Reich.

Prof. Richard KuhN, director of the Kaiser Wilhelm Institute for Medical Research at Heidelberg, and Dr. Ernst Späth, professor of chemistry at Vienna, have been elected honorary members of the Société de Chimie Industrielle of Paris.

Prof. Max Eugling, who is well known for his climatic and hydrological researches, has succeeded Prof. Grassberger as chief of the Institute of Hygiene of the University of Vienna, where he has been assistant for the last thirty years.

THE second Darling prize of the League of Nations for original work on malaria published during the previous five years has been awarded to Prof. N. H. Swellengrebel, professor of tropical parasitology at Amsterdam, and will be awarded to him during the Third International Congress on Malariology in September 1938.

ThE Association for Education in Citizenship has arranged a secondary school conference on methods of training for the responsibilities of citizenship, to be held at Morley College, Westminster Bridge Road, London, S.E.1, on March 4-6. Applications to attend the conference, accompanied by a fee of $5 s$., should reach the secretary of the Association, 10 Victoria Street, London, S.W.1, not later than February 5. 